\title{
Neointimal characteristics comparison between biodegradable- polymer and durable-polymer drug-eluting stents: 3-month follow-up optical coherence tomography light property analysis from the RESTORE registry
}

\author{
Tomoaki Kobayashi ${ }^{1}$. Yohei Sotomi ${ }^{1}$. Satoshi Suzuki ${ }^{1}$ 'Yuma Hamanaka ${ }^{1}$ Shimpei Nakatani ${ }^{1}$. Jouke Dijkstra ${ }^{2}$. \\ Yoshinobu Onuma $^{3,4} \cdot$ Patrick W. Serruys $^{5} \cdot$ Yasushi Sakata $^{6} \cdot$ Atsushi Hirayama $^{1} \cdot$ Yoshiharu Higuchi $^{1}$
}

Received: 26 May 2019 / Accepted: 18 October 2019

(c) Springer Nature B.V. 2019

\begin{abstract}
We aimed to quantitatively assess a possible difference of the neointimal quality between biodegradable polymer- (BP-) and durable polymer drug-eluting stents (DP-DESs). We conducted a single-center all-comer prospective cohort study: the RESTORE registry (UMIN000033009). All patients who received successful OCT examination at planned 3-month follow-up after DES implantation were analyzed. Study population was divided into 2 groups, BP-DES versus DP-DES groups. We evaluated standard OCT variables, coverage percent, and the quantitative light property values including light intensity, attenuation, and backscatter. We performed OCT analyses of 121 lesions in 98 patients (BP-DES 55 lesions in 51 patients vs. DP-DES 66 lesions in DP-DES 53 patients). Lesion and procedural characteristics were overall well-balanced between both groups. At 3-month follow-up, neointimal thickness (BP-DES 49.3 [38.2, 57.7] $\mu \mathrm{m}$ versus DP-DES 54.7 [45.1, 70.7] $\mu \mathrm{m}, \mathrm{p}=0.059$ ) and coverage percent (BP-DES $94.5[89.8,97.0] \%$ vs. DP-DES $95.8[91.1,98.1] \%, \mathrm{p}=0.083$ ) did not significantly differ. Light intensity of superficial neointima in the BP-DES was lower than that in the DP-DES, whereas that of deep neointima did not differ between both groups. Both superficial and deep neointima of the BP-DES presented significantly lower light attenuation and backscatter than those of the DP-DES did. Almost complete coverage at 3 months in both contemporary BP- and DP-DES would support the ultra-short DAPT strategy in the upcoming decade. Nevertheless, there was a significant difference in the neointimal characteristics on OCT light property 3 months after BP- versus DP-DES implantation.
\end{abstract}

Trial Registration UMIN000033009.

Keywords Optical coherence tomography $\cdot$ Light property analysis $\cdot$ Drug-eluting stent $\cdot$ Biodegradable polymer $\cdot$ Durable polymer

Yohei Sotomi

sotomiyohei@gmail.com

1 Department of Cardiology, Osaka Police Hospital, 10-31, Kitayama, Tennoji, Osaka 543-0035, Japan

2 Department of Radiology, Leiden University Medical Center, Leiden, The Netherlands

3 Thoraxcenter, Erasmus Medical Center, Rotterdam, The Netherlands

4 Cardialysis, Rotterdam, The Netherlands

5 International Centre for Circulatory Health, NHLI, Imperial College London, London, UK

6 Department of Cardiovascular Medicine, Osaka University Graduate School of Medicine, Osaka, Japan

\section{Introduction}

The contemporary biodegradable polymer DES (BP-DES) has thinner struts and an abluminal very thin coat of biodegradable polymer which is fully absorbed in 3-4 months in a synchronous way with the drug. Abluminal coating technology of the contemporary BP-DESs, Synergy ${ }^{\mathrm{TM}}$ (Boston Scientific Corporation, Natick, MA, USA) and Ultimaster ${ }^{\mathrm{TM}}$ (Terumo Corp., Tokyo, Japan) is expected to enhance the early neointimal coverage. Animal study suggested that the technology may promote a more complete and quick healing process with these stents in acute phase [1]. An imaging study of the Ultimaster ${ }^{\mathrm{TM}}$ BP-DES in human presented 
almost complete coverage of struts at 3-month follow-up on optical coherence tomography (OCT) [2], which might represent the expected early vessel healing. However, precise imaging data of these theoretical benefits of the contemporary BP-DES including strut coverage and neointimal quality in comparison with the current durable polymer DES (DPDES) is still scarce [3].

Several studies reported the usefulness of OCT light intensity, light attenuation and light backscatter to characterize the tissue components of coronary artery [4]. In a histological study, it was demonstrated that the increased light attenuation and light backscatter were associated with lipid-rich plaque and macrophages, while increased light intensity was related to tissue maturity [4-6].

We aimed to assess a possible difference of the neointimal coverage and its quality between BP- and DP-DESs by a quantitative light property analysis on OCT.

\section{Materials and methods}

\section{Study design and population}

Study design was a single-center prospective cohort study: the RESTORE registry (UMIN000033009). In the RESTORE registry, all patients treated with current DES are planned to perform follow-up imaging evaluation 3 months and 24 months ( \pm 1 month) after the index procedure with OCT and coronary angioscopy. The 3-month results of coronary angioscopy were reported elsewhere [7]. In the present acute-phase OCT analysis, all patients who received successful OCT examination at planned 3 months follow-up ( \pm 1 month) after the DES implantation in the native coronary artery irrespective of clinical presentation (silent myocardial ischemia, stable or unstable angina, ST elevation myocardial infarction, or non-ST elevation myocardial infarction) without any earlier event of stent failure were analyzed. Synergy ${ }^{\mathrm{TM}}$ and Ultimaster ${ }^{\mathrm{TM}}$ were defined as BP-DESs, while Resolute ${ }^{\mathrm{TM}}$ zotarolimus-eluting stent (Medtronic CardioVascular, CA, USA), Xience ${ }^{\mathrm{TM}}$ cobalt chromium everolimus-eluting stent (Abbott Vascular, Santa Clara, CA, USA) were categorized as DP-DESs. Written informed consent was obtained from all enrolled patients. This study was approved by the Osaka Police Hospital Ethical Committee.

\section{Procedure}

Percutaneous coronary intervention (PCI) strategy was left to the discretion of the individual operators. Dual antiplatelet therapy (DAPT, aspirin and $\mathrm{P}_{2} \mathrm{Y}_{12}$ inhibitor) was encouraged to keep at least 6 months after the PCI. All patients and treating physicians were asked to adhere to the Guideline of the Japanese Society of Cardiology in terms of tobacco usage, exercise, healthy food intake, maintenance of an adequate body weight, and medications for the achievement of target blood lipid concentrations, and blood pressure control.

\section{OCT analysis}

Angiographic and OCT imaging follow-up was conducted 3 months after the index procedure. OCT assessment of the stented coronary segment was performed using the OPTIS ${ }^{\circledR}$ console and the Dragonfly ${ }^{\circledR}$ catheter (both Abbott Vascular, Santa Clara, CA, USA). The off-line OCT measurements were performed with QCU-CMS software (version 4.69; Leiden University Medical Center, Leiden, the Netherlands) by independent investigators (TK, YS, SN, and SS). With adjustment for the pullback speed, the analysis of continuous cross-sections was performed at each $1 \mathrm{~mm}$ longitudinal interval within the treated segment. Lumen contour was defined as the continuous interface between a blood and non-blood structure. The endoluminal metallic stent contour was delineated by a curvilinear interpolation connecting the midpoints of the endoluminal leading edge of the reflective border. The abluminal stent contour was automatically drawn by simulating the virtual contour of the struts. After identifying all struts in a cross-section, the abluminal stent contour was delineated by a curvilinear interpolation connecting the middle points of the abluminal edge of virtual metallic struts. Thickness of the virtual strut was determined by the reported strut thickness of each stent type (Synergy $74 \mu \mathrm{m}$, Ultimaster $80 \mu \mathrm{m}$, Xience $81 \mu \mathrm{m}$, Resolute Onyx $81 \mu \mathrm{m}$, Resolute Integrity $91 \mu \mathrm{m}$ ).

In the current study, light property analysis was additionally performed to investigate the neointimal quality quantitatively. The dedicated software (QCU-CMS software version 4.69) was employed for the quantitative light property analysis of the vessel wall. The software was used to calculate the attenuation and backscattering coefficients based on a depth-resolved model [8]. The following parameters were analyzed within the neointimal area of interest defined with the contours delineated by the investigators: light intensity (no unit), (2) light attenuation ( $\mathrm{mm}^{-1}$ ), and (3) backscatter (no unit). The light intensity indicates the amount of light signal detected at a certain location in the vessel wall based on reflection and backscatter. The light attenuation, estimated as the depth-resolved attenuation coefficient in this study, indicates how fast the light signal is decayed. It is the rate of exponential decreasing intensity related to the light propagation depth. Concretely, the total incident light power $I_{0}$ is decreased to be $I_{0 / \mathrm{e}}$ at depth $1 / \mu_{\mathrm{t}}$. The backscatter, estimated as the depth-resolved backscattering coefficient in this study, is related to the efficiency of tissue scattering 
the light backwards [8]. The neointimal area of interest was assessed separately as the following two parts: (1) superficial neointima (delineated by the luminal contour and the interpolated contour connecting the endoluminal edges of struts [endoluminal stent contour]), (2) deep neointima (delineated by the endoluminal and abluminal stent contours, excluding strut area) (Fig. 1). Each parameter was computed at every cross-section as an average in the area of interest. The analysis of continuous cross-sections was performed at each $1 \mathrm{~mm}$ longitudinal interval within the stented segment. The mean value in each stent lesion was calculated as a lesion level data. The reproducibility of the neointimal analysis depends only on the contour delineation since the software is fully automatic. The reproducibility of the OCT standard analysis with the current software was published elsewhere [9].

\section{Statistical analysis}

Study population was divided into 2 groups, BP-DES (Synergy $^{\mathrm{TM}}$ and Ultimaster ${ }^{\mathrm{TM}}$ ) versus DP-DES (Xience ${ }^{\mathrm{TM}}$, Resolute Integrity ${ }^{\mathrm{TM}}$ and Resolute Ony $\mathrm{x}^{\mathrm{TM}}$ ) groups. Normality of data distribution was tested by the Kolmogorov-Smirnov test. Data are expressed as mean \pm SD or median and interquartile range. Group means for continuous variables with normal and non-normal distributions were compared using Student's t-tests and Mann-Whitney U tests, respectively. Categorical variables were compared using the Pearson's chi-square test or Fischer's exact test, as appropriate. Mixed linear model with an assumed Gaussian distribution was used for the comparisons of continuous light property variables to take into an account the clustered nature of $>1$ strut, $>1$ cross section, $>1$ lesion analyzed from the same patients which might result in unknown correlations among measurements within the clusters. All statistical analyses were performed with SPSS (version 24.0.0, IBM, New York).

\section{Results}

\section{Study population}

A total of 110 patients with 133 lesions (mean age $66.8 \pm 9.9$ years) were enrolled from May 2016 to April 2018 (BP-DES 59 patients 63 lesions vs. DP-DES 57 patients 70 lesions). Six patients had both BP-DES and DPDES. Eight lesions in 8 patients and 4 lesions in 4 patients were excluded due to insufficient OCT image quality in the BP-DES and DP-DES groups, respectively. As a result, we performed OCT analyses of 121 lesions in 98 patients (BPDES 55 lesions in 51 patients vs. DP-DES 66 lesions in DP-DES 53 patients) (Fig. 2). The median invasive imaging follow-up time was 102 days after the index procedure. Table 1 shows patient and lesion demographics, risk factors, and medication. Serum profiles including low-density lipoprotein cholesterol, high-density lipoprotein cholesterol, and triglycerides were not different between both groups. Lesion and procedural characteristics were overall wellbalanced(Table 2). Approximately half of the lesions were

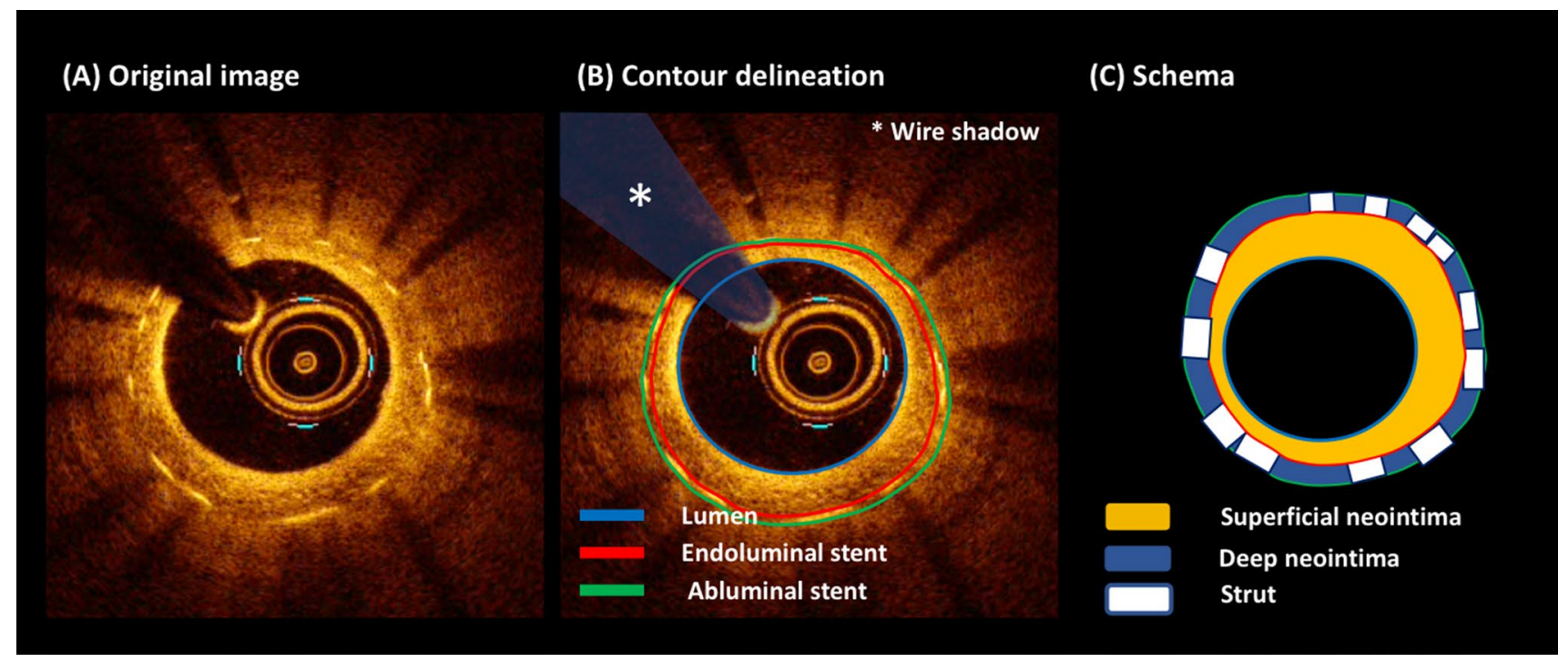

Fig. 1 Neointimal area compartments analyzed by optical coherence tomography. Image example of OCT at three-month follow-up for BP-DES and DP-EES (A). Lumen contour (blue), endoluminal (red) and abluminal (green) stent contours were delineated semi-automatically (B). The neointimal area of interest was assessed separately as the following two parts: (1) superficial neointima (delineated by the luminal contour and the interpolated contour connecting the endoluminal edges of struts [endoluminal stent contour]) (yellow area in c); (2) deep neointima (delineated by the endoluminal and abluminal stent contours, excluding strut area) (blue area in $\mathbf{C}$ ) 


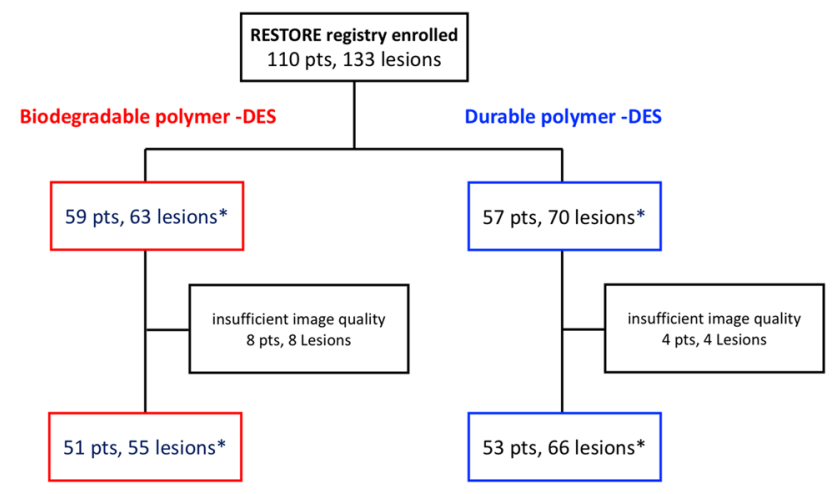

Fig. 2 Patient flowchart. A total of 110 patients with 133 lesions were enrolled from May 2016 to April 2018. Sufficient image quality of OCT was obtained in 121 lesions out of 133 lesions (90.9\%). As a result, a total of 98 patients with 121 lesions were analyzed (biodegradable polymer-DES 55 lesions in 51 patients vs. durable polymerDES 66 lesions in 53 patients). *Six patients had both BP-DES and DP-DES. OCT optical coherence tomography, DES drug-eluting stent

left anterior descending artery. Only pre-dilatation balloon diameter was significantly larger in the DP-DES group than in the BP-DES group.

\section{OCT findings at 3-month follow-up}

Table 3 summarizes the OCT results. Lumen area was comparable between both groups. Endoluminal stent area was also comparable. The abluminal stent area of DP-DES was significantly larger than that of BP-DES. Neointimal thickness (BP-DES 49.3 [38.2, 57.7] $\mu \mathrm{m}$ vs. DP-DES 54.7 [45.1, 70.7] $\mu \mathrm{m}, \mathrm{p}=0.059$ ) and coverage percent (coverage \%; BPDES $94.5[89.8,97.0] \%$ vs. DP-DES $95.8[91.1,98.1] \%$, $\mathrm{p}=0.083$ ) did not significantly differ between both groups.

\section{Neointimal characteristics on light property analysis}

Table 3 and Fig. 3 summarizes the results of OCT analysis. Light intensity of superficial neointima in the BP-DES group was lower than that in the DP-DES group (120.2 [102.9, 154.8] vs. 170.9 [117.6, 227.4], $\mathrm{p}<0.001$ ), whereas deep neointima in the BP-DES showed comparable to that in the DP-DES. (189.3 [151.9, 254.7] vs. 210.5 [168.8, 254.6], $\mathrm{p}=0.474)$. Light attenuation of both superficial and deep neointima in the BP-DES group was significantly lower as compare to the DP-DES group (superficial; 0.71 [0.62, $0.80] \mathrm{mm}^{-1}$ vs. $0.93[0.71,1.16] \mathrm{mm}^{-1}, \mathrm{p}<0.001$ : deep; $1.09[0.96,1.22]$ vs. $1.20[1.05,1.34] \mathrm{mm}^{-1}, \mathrm{p}=0.008$ ). Backscatter of superficial and deep neointima in the BP-DES was also significantly lower than that in the DP-DES group (superficial; $4.47[4.23,4.76]$ vs. $5.02[4.59,5.51], \mathrm{p}<0.001$ : deep; $5.03[4.71,5.28]$ vs. $5.25[5.00,5.57] \mathrm{p}=0.002)$.

\section{Influencing factors of the neointimal optical characteristics at 3-month follow-up}

To investigate the factors associated with the light characteristics of the superficial neointima, multivariate analysis was

Table 1 Patients' characteristics

\begin{tabular}{|c|c|c|c|}
\hline & $\begin{array}{l}\text { BP-DES } \\
\mathrm{N}=51 \text { patients }^{\mathrm{a}}\end{array}$ & $\begin{array}{l}\text { DP-DES } \\
\mathrm{N}=53 \text { patients }^{\mathrm{a}}\end{array}$ & $\mathrm{p}$ value \\
\hline Age (years) & $66.29 \pm 9.88,67.00[60.00,74.00]$ & $68.42 \pm 10.01,70.00[62.00,76.00]$ & 0.297 \\
\hline Body mass index $\left(\mathrm{kg} / \mathrm{m}^{2}\right)$ & $24.38 \pm 3.89,23.80[21.80,26.30]$ & $25.21 \pm 3.47,24.40[22.70,27.70]$ & 0.124 \\
\hline Male $(\%)$ & $43 / 51(84.3)$ & $44 / 53(83.0)$ & 0.999 \\
\hline Diabetes Mellitus (\%) & $26 / 51(51.0)$ & $29 / 53(54.7)$ & 0.844 \\
\hline Hypertension (\%) & $37 / 51(72.5)$ & $48 / 53(90.6)$ & 0.022 \\
\hline Current smoker $(\%)$ & $7 / 51(13.7)$ & $6 / 53(11.3)$ & 0.773 \\
\hline \multicolumn{4}{|c|}{ Serum lipid profile at 3-month follow-up (mg/dl) } \\
\hline Low-density lipoprotein cholesterol & $85.74 \pm 23.38,83.50[66.25,100.50]$ & $81.02 \pm 21.31,79.00[67.00,99.00]$ & 0.523 \\
\hline High-density lipoprotein cholesterol & $49.36 \pm 14.96,46.00[41.25,55.75]$ & $47.04 \pm 12.00,44.00[40.00,54.00]$ & 0.407 \\
\hline Triglycerides & $142.20 \pm 75.59,120.50[88.50,178.50]$ & $138.91 \pm 78.19,116.00[89.00,173.00]$ & 0.836 \\
\hline \multicolumn{4}{|l|}{ Medication at 3-month follow-up } \\
\hline Statin $(\%)$ & $38 / 51(74.5)$ & $46 / 53(86.8)$ & 0.139 \\
\hline Aspirin (\%) & $51 / 51(100.0)$ & $53 / 53(100.0)$ & 0.999 \\
\hline Clopidogrel (\%) & $19 / 51(37.3)$ & $25 / 53(47.2)$ & 0.328 \\
\hline Prasugrel (\%) & 29/51 (56.9) & $29 / 53(54.7)$ & 0.846 \\
\hline Follow-up duration (day) & $108.31 \pm 29.82,102.00[93.00,116.00]$ & $102.92 \pm 17.69,102.00[92.00,112.00]$ & 0.449 \\
\hline
\end{tabular}

Data are expressed as mean \pm standard deviation, median [interquartile range], and number (percentage)

${ }^{a}$ Six patients had both BP-DES and DP-DES 
Table 2 Procedural characteristics

\begin{tabular}{|c|c|c|c|}
\hline & $\begin{array}{l}\mathrm{BP} \text { stent } \\
\mathrm{N}=55 \text { lesions }\end{array}$ & $\begin{array}{l}\text { DP stent } \\
\mathrm{N}=66 \text { lesions }\end{array}$ & $\mathrm{p}$ value \\
\hline Acute coronary syndrome $(\%)$ & $12 / 55(21.8)$ & $19 / 66(28.8)$ & 0.414 \\
\hline \multicolumn{4}{|l|}{ Target vessel } \\
\hline Right coronary artery (\%) & $16 / 55(29.1)$ & $22 / 66(33.3)$ & \multirow[t]{4}{*}{0.132} \\
\hline Left anterior descending artery $(\%)$ & $24 / 55(43.6)$ & $37 / 66(56.1)$ & \\
\hline Left circumflex artery $(\%)$ & $11 / 55(20.0)$ & $5 / 66(7.6)$ & \\
\hline Left main trunk $(\%)$ & $4 / 55(7.3)$ & $2 / 66(3.0)$ & \\
\hline Pre-dilatation performed & $47 / 55(85.5)$ & $60 / 66(90.9)$ & 0.580 \\
\hline Pre-dilatation balloon diameter (mm) & $2.53 \pm 0.52,2.50[2.00,4.00]$ & $2.85 \pm 0.68,2.62[2.00,5.00]$ & 0.009 \\
\hline Pre-dilatation balloon pressure (atm) & $12.50 \pm 2.96,12.00[6.00,18.00]$ & $12.42 \pm 3.72,12.00[4.00,22.00]$ & 0.900 \\
\hline \multicolumn{4}{|l|}{ Stenting } \\
\hline Stent number & $1.16 \pm 0.37,1.00[1.00,1.00]$ & $1.30 \pm 0.49,1.00[1.00,2.00]$ & 0.100 \\
\hline Stet diameter $(\mathrm{mm})$ & $3.02 \pm 0.47,3.00[2.75,3.50]$ & $3.05 \pm 0.50,3.00[2.50,3.50]$ & 0.860 \\
\hline Stent length $(\mathrm{mm})$ & $41.08 \pm 19.10,38.00[28.00,52.00]$ & $36.67 \pm 23.39,30.00[22.00,38.00]$ & 0.253 \\
\hline Stent implantation pressure (atm) & $13.23 \pm 2.66,14.00[12.00,14.00]$ & $14.03 \pm 2.46,14.00[12.00,16.00]$ & 0.084 \\
\hline Post-dilatation performed & $44 / 55(80.0)$ & $53 / 66(80.3)$ & 0.999 \\
\hline Post-dilatation balloon diameter (mm) & $3.27 \pm 0.63,3.05[2.00,5.00]$ & $3.92 \pm 3.75,3.25[2.25,30.00]$ & 0.264 \\
\hline Post-dilatation pressure (atm) & $16.18 \pm 4.02,16.00[6.00,22.00]$ & $16.73 \pm 3.59,17.00[8.00,22.00]$ & 0.481 \\
\hline \multicolumn{4}{|l|}{ Stent type } \\
\hline Synergy (\%) & $26 / 55(47.3)$ & - & \\
\hline Ultimaster (\%) & $29 / 55(52.7)$ & - & \\
\hline Xience (\%) & - & $28 / 66(42.4)$ & \\
\hline Resolute (\%) & - & $38 / 66(57.6)$ & \\
\hline
\end{tabular}

Data are expressed as mean \pm standard deviation, median [interquartile range], and number (percentage)

Table 3 Three-month quantitative neointimal assessments on OCT

\begin{tabular}{|c|c|c|c|}
\hline & $\begin{array}{l}\text { BP-DES } \\
\mathrm{N}=55 \text { lesions }\end{array}$ & $\begin{array}{l}\text { DP-DES } \\
\mathrm{N}=66 \text { lesions }\end{array}$ & $\mathrm{p}$ value \\
\hline Stent length (mm) & $37.20 \pm 12.16,37.20[30.00,43.80]$ & $31.83 \pm 14.01,28.90[20.60,38.00]$ & 0.028 \\
\hline Mean lumen area $\left(\mathrm{mm}^{2}\right)$ & $6.13 \pm 2.04,5.53[4.80,7.27]$ & $6.80 \pm 2.34,6.39[4.99,7.90]$ & 0.097 \\
\hline Mean endoluminal stent area $\left(\mathrm{mm}^{2}\right)$ & $6.35 \pm 2.05,6.05[4.86,7.65]$ & $7.11 \pm 2.30,6.50[5.46,8.19]$ & 0.060 \\
\hline Mean abluminal stent area $\left(\mathrm{mm}^{2}\right)$ & $7.04 \pm 2.15,6.71[5.50,8.42]$ & $7.89 \pm 2.41,7.25[6.15,9.02]$ & 0.047 \\
\hline Mean neointimal thickness $(\mu \mathrm{m})$ & $52.49 \pm 21.21,49.33[38.23,57.71]$ & $62.79 \pm 32.25,54.76[45.06,70.68]$ & 0.059 \\
\hline Coverage percent $(\%)$ & $92.45 \pm 6.37,94.54[89.77,97.04]$ & $94.45 \pm 4.56,95.84[91.06,98.05]$ & 0.083 \\
\hline \multicolumn{4}{|l|}{ Light property analysis } \\
\hline \multicolumn{4}{|l|}{ Superficial neointima } \\
\hline Light intensity & $130.48 \pm 44.23,120.24[102.91,154.76]$ & $178.04 \pm 67.07,170.85[117.58,227.36]$ & $<0.001$ \\
\hline Light attenuation & $0.73 \pm 0.14,0.71[0.62,0.80]$ & $0.94 \pm 0.27,0.93[0.71,1.16]$ & $<0.001$ \\
\hline Backscatter & $4.50 \pm 0.42,4.47[4.23,4.76]$ & $5.00 \pm 0.59,5.02[4.59,5.51]$ & $<0.001$ \\
\hline \multicolumn{4}{|l|}{ Deep neointima } \\
\hline Light intensity & $201.15 \pm 70.64,189.35[151.87,254.67]$ & $209.88 \pm 63.10,210.49[168.84,254.58]$ & 0.474 \\
\hline Light attenuation & $1.09 \pm 0.20,1.09[0.96,1.22]$ & $1.19 \pm 0.22,1.20[1.05,1.34]$ & 0.010 \\
\hline Backscatter & $4.96 \pm 0.45,5.03[4.71,5.28]$ & $5.23 \pm 0.48,5.25[5.00,5.57]$ & 0.002 \\
\hline
\end{tabular}

Data are expressed as mean \pm standard deviation, median [interquartile range] 


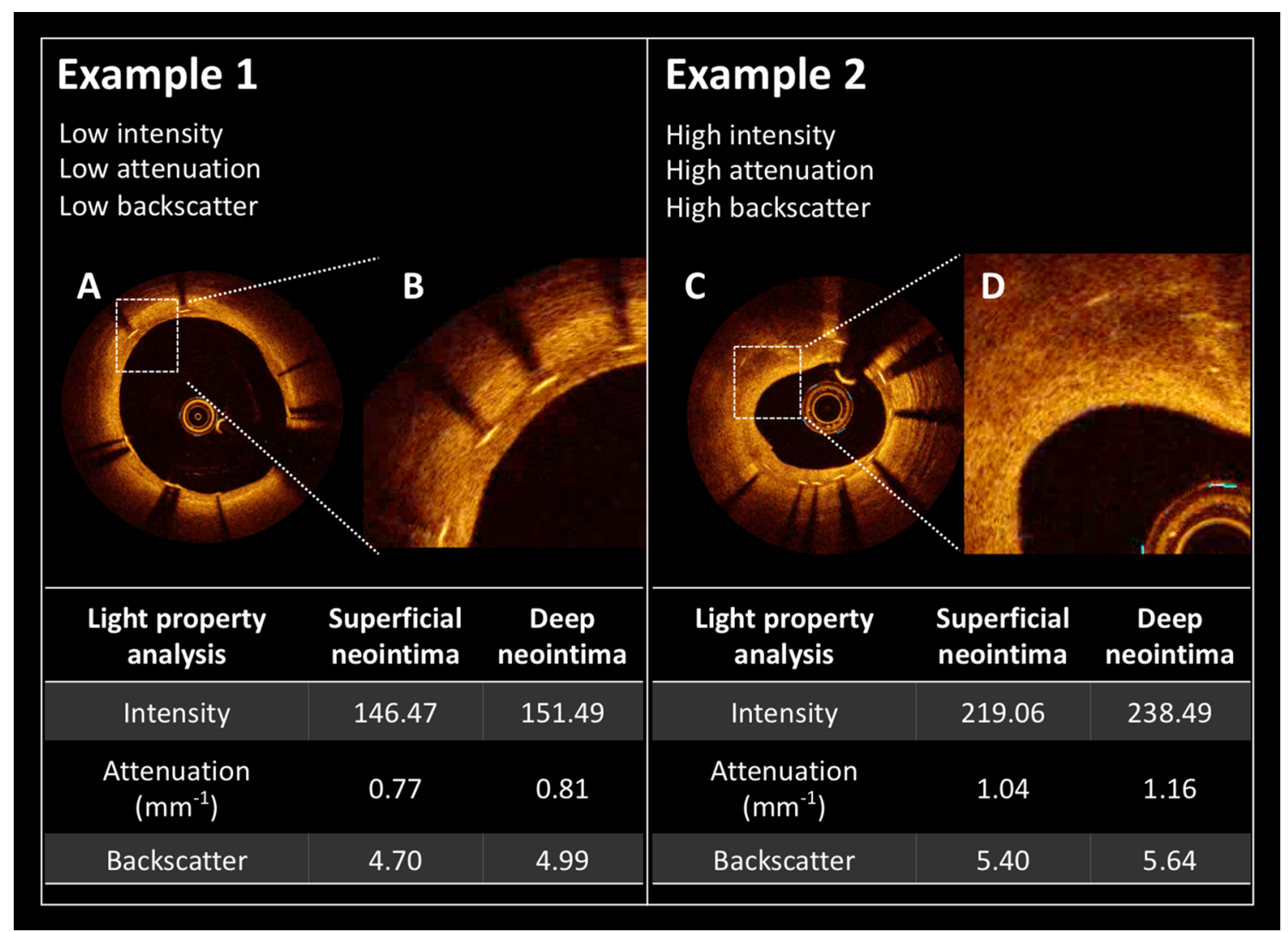

Fig. 3 Imaging examples. Image examples of light property analysis are presented. The dedicated software full-automatically computed, based on the original image (A-D), three components of light property analysis (1) light intensity, (2) light attenuation and (3) backscatter

conducted using linear regression analysis (Table 4). BPDES usage was significantly and strongly associated with lower intensity, lower attenuation, and lower backscatter.

\section{Discussion}

Main findings of the present study can be summarized as follows: (1) At 3-month follow-up, neointimal thickness and coverage $\%$ were not significantly different between the BPand the DP-DES groups; (2) light intensity of superficial neointima in the BP-DES was lower than that in the DPDES, whereas that of deep neointima did not differ between both groups; (3) both superficial and deep neointima of the BP-DES presented significantly lower light attenuation and backscatter as compared to that of the DP-DES.

\section{Strut coverage in the BP- and the DP-DES}

The present study demonstrated the comparable coverage percent between BP-DES and DP-DES, which was in line with the previous reports. At 3-month follow-up, the Ultimaster ${ }^{\mathrm{TM}}$ BP-DES and the Synergy ${ }^{\mathrm{TM}}$ BP-DES achieved similar strut coverage percent of $95.2 \%$ and
94.5\%, respectively $[2,10,11]$, while the Xience ${ }^{\mathrm{TM}}$ DPDES and the Resolute ${ }^{\mathrm{TM}}$ DP-DES also showed the coverage percent of $94.5 \%$ and $93.8 \%$, respectively $[12,13]$. Both previous and the present studies showed comparable neointimal coverage percent after implantation of the contemporary BP- and DP-DESs assessed by OCT. Nevertheless, recent clinical trials (STOP DAPT 2, SENIOR, etc.) have proved the feasibility of ultra-short dual antiplatelet therapy (1-month DAPT), implying that the OCT coverage might not be a suitable surrogate for the vessel healing after stent implantation [14]. Not only neointimal coverage percent but also objective quality assessment of the neointima would be necessary in order to assess the vessel healing status more appropriately (Fig. 4).

\section{Interpretation of the light properties}

The present study demonstrated the different neointimal characteristic between BP- and DP-DES with the dedicated software. We validated the software with histology and demonstrated consistently similar relationship on tissue characteristics with previous reports [4-6]. Light intensity is positively correlated with maturation of the neointimal tissue [15]. In animal and human autopsy specimens, mature 
Table 4 Determinants of light intensity, attenuation, and backscatter on OCT at 3-month follow-up

\begin{tabular}{|c|c|c|c|c|c|c|c|c|c|}
\hline \multirow[t]{2}{*}{ Variables } & \multicolumn{3}{|c|}{ Light intensity } & \multicolumn{3}{|c|}{ Light attenuation } & \multicolumn{3}{|c|}{ Backscatter } \\
\hline & $\begin{array}{l}\text { Beta coeffi- } \\
\text { cient }\end{array}$ & $95 \% \mathrm{CI}$ & $\mathrm{p}$ value & $\begin{array}{l}\text { Beta coef- } \\
\text { ficient }\end{array}$ & $95 \% \mathrm{CI}$ & $\mathrm{p}$ value & $\begin{array}{l}\text { Beta coef- } \\
\text { ficient }\end{array}$ & $95 \% \mathrm{CI}$ & $\mathrm{p}$ value \\
\hline BP-DES usage & -44.738 & $\begin{array}{c}{[-66.415,-} \\
23.060]\end{array}$ & $<0.001$ & -0.190 & $\begin{array}{c}{[-0.273,-} \\
0.108]\end{array}$ & $<0.001$ & -0.455 & $\begin{array}{c}{[-0.646,-} \\
0.265]\end{array}$ & $<0.001$ \\
\hline Age (year) & 1.050 & $\begin{array}{c}{[-0.082} \\
2.181]\end{array}$ & 0.069 & 0.004 & {$[0.000,0.009]$} & 0.046 & 0.011 & {$[0.001,0.021]$} & 0.030 \\
\hline Male gender & 20.134 & $\begin{array}{r}{[-13.17} \\
53.438]\end{array}$ & 0.233 & 0.044 & $\begin{array}{c}{[-0.083,} \\
0.171]\end{array}$ & 0.493 & 0.237 & $\begin{array}{c}{[-0.056,} \\
0.53]\end{array}$ & 0.112 \\
\hline $\begin{array}{l}\text { Current } \\
\text { smoker }\end{array}$ & -2.499 & $\begin{array}{c}{[-30.421} \\
25.423]\end{array}$ & 0.860 & -0.032 & $\begin{array}{c}{[-0.138,} \\
0.074]\end{array}$ & 0.551 & -0.032 & $\begin{array}{c}{[-0.278,} \\
0.213]\end{array}$ & 0.794 \\
\hline Hypertension & 6.099 & $\begin{array}{r}{[-4.501} \\
16.699]\end{array}$ & 0.257 & 0.042 & {$[0.001,0.082]$} & 0.043 & 0.095 & {$[0.002,0.189]$} & 0.045 \\
\hline $\begin{array}{l}\text { Acute } \\
\text { coronary } \\
\text { syndrome }\end{array}$ & -4.483 & $\begin{array}{c}{[-29.312} \\
20.347]\end{array}$ & 0.721 & 0.004 & $\begin{array}{c}{[-0.091} \\
0.098]\end{array}$ & 0.938 & 0.000 & $\begin{array}{c}{[-0.219} \\
0.218]\end{array}$ & 0.997 \\
\hline Hypertension & 6.099 & $\begin{array}{r}{[-4.501} \\
16.699]\end{array}$ & 0.257 & 0.042 & {$[0.001,0.082]$} & 0.043 & -0.022 & $\begin{array}{c}{[-0.266,} \\
0.223]\end{array}$ & 0.861 \\
\hline $\begin{array}{l}\text { Diabetes mel- } \\
\text { litus }\end{array}$ & 16.747 & $\begin{array}{r}{[-4.655,} \\
38.149]\end{array}$ & 0.124 & 0.015 & $\begin{array}{c}{[-0.067,} \\
0.096]\end{array}$ & 0.719 & 0.071 & $\begin{array}{c}{[-0.118,} \\
0.259]\end{array}$ & 0.459 \\
\hline Statin use & -12.101 & $\begin{array}{c}{[-39.664} \\
15.462]\end{array}$ & 0.386 & -0.061 & $\begin{array}{c}{[-0.166,} \\
0.044]\end{array}$ & 0.252 & -0.107 & $\begin{array}{c}{[-0.350,} \\
0.135]\end{array}$ & 0.382 \\
\hline Prasugrel use & -3.751 & $\begin{array}{c}{[-25.787} \\
18.286]\end{array}$ & 0.737 & -0.034 & $\begin{array}{c}{[-0.118,} \\
0.050]\end{array}$ & 0.423 & -0.040 & $\begin{array}{c}{[-0.234,} \\
0.153]\end{array}$ & 0.680 \\
\hline $\begin{array}{l}\text { FUP duration } \\
\text { (days) }\end{array}$ & 0.025 & $\begin{array}{c}{[-0.429} \\
0.480]\end{array}$ & 0.912 & 0.000 & $\begin{array}{c}{[-0.002,} \\
0.002]\end{array}$ & 0.959 & 0.000 & $\begin{array}{c}{[-0.004,} \\
0.004]\end{array}$ & 0.935 \\
\hline
\end{tabular}

The linear regression analysis on light property of the superficial neointima was performed

neointimal tissue with a predominance of smooth muscle cells show higher greyscale signal intensity values and lower attenuation/backscatter values. Immature tissue with fiber rich extracellular matrix, infrequent smooth muscle cells, interspersed inflammatory cells, and fibrin show lower signal intensity values and lower attenuation/backscatter. Lipidrich plaque and necrotic core exhibit strong light attenuation and backscatter with low intensity values [4-6]. Macrophage infiltration and erythrocytes indicate high intensity with high attenuation due to their lipid components [15].

It might be challenging to interpret the current results based on the previous validation data since no validation data was available in the very early phase like ours. Therefore, we can have only speculative interpretation of the current findings as follows. In the present study, the DP-DES had higher light intensity and higher light attenuation/backscatter values than the BP-DES. High light intensity with high attenuation/backscatter might be interpreted as macrophage infiltration or thrombus with erythrocytes whose membranes contain a large amount of lipid (40\%) [16, 17]. Angioscopic observation of the current cohort provided the numerically higher rate of thrombus in the DP-DES than in the BP-DES ( $25 \%$ vs. $21 \%, \mathrm{p}=0.357)$, which might support this interpretation [7]. Biological responses in stented arteries can be divided into three different time phases [18, 19]: (1) thrombosis/acute inflammation, (2) granulation tissue, and (3) tissue remodeling phase. Theoretical change of the light property values is illustrated in Fig. 5. BP-DES showed lower light intensity and lower light attenuation/ backscatter values than DP-DES did. Different light intensity and attenuation/backscatter between the DP-DES and the BP-DES might indicate that, at 3 months after stent implantation, the BP-DES might be in a slightly advanced phase as compared with the DP-DES. Note that the changes of light property values presented in Fig. 5 is theoretical and speculative. Further validation data in acute phase would be warranted to interpret our results appropriately. The only thing we can say from the current results is that there may be some significant differences in the neointimal characteristics 3 months after DES implantation. Whether the current "statistically" significant difference has a clinical impact is also yet to be investigated. The recent meta-analysis comparing "long-term" clinical data of the BP- and the DP-DES demonstrated similar clinical outcomes between both groups [20]. However, clinical relevance of the current results with very-short term rather than long-term outcomes would be of more interest in the current ultra-short DAPT era. The present study did not have enough power to assess this point. 

(A) Light intensity
(B) Light attenuation
(C) Backscatter

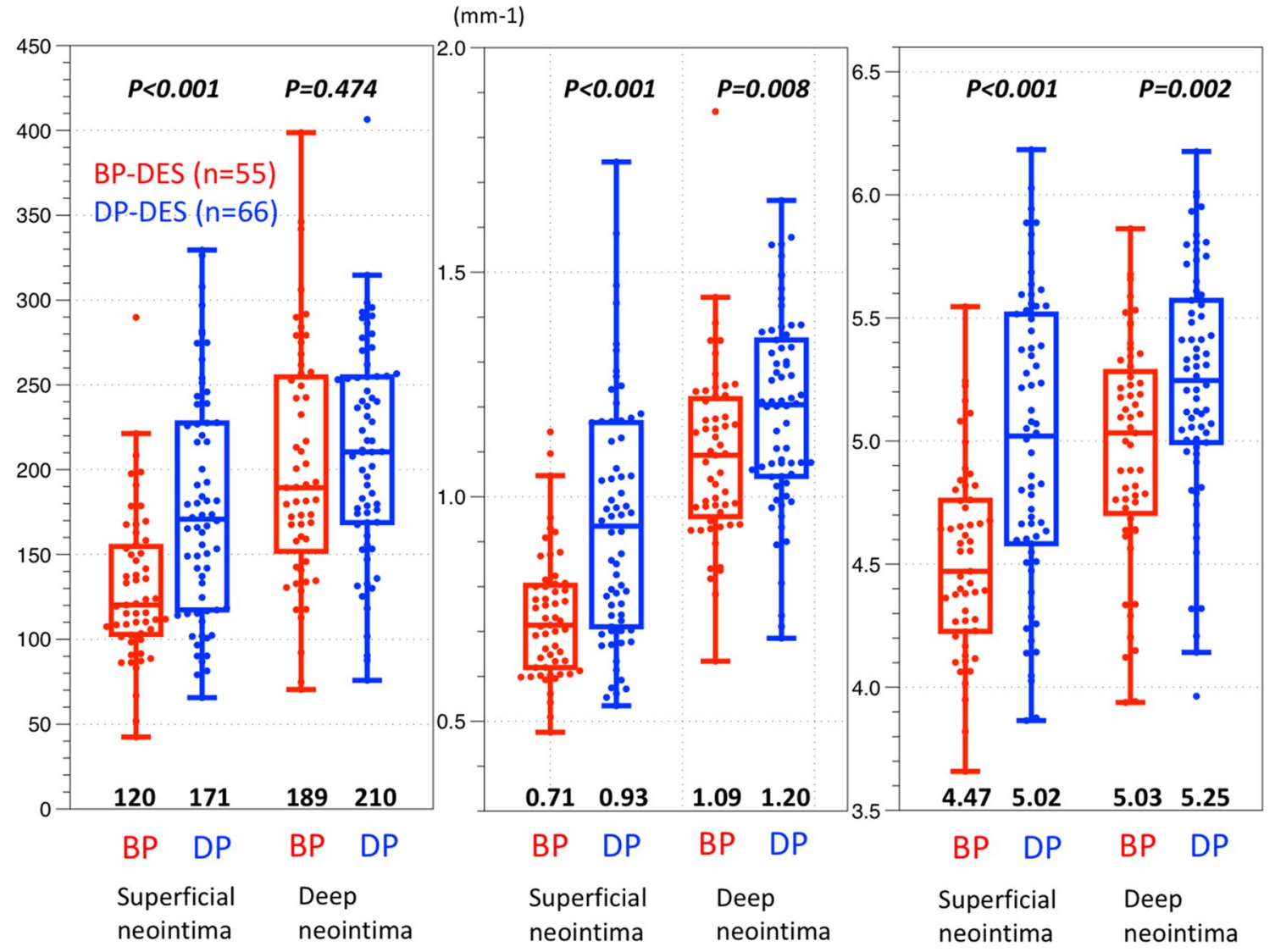

Fig. 4 Neointimal quality assessment by light property analysis. Neointimal quality was quantitatively assessed for BP-DES (red) and DP-DES (blue) by light property analysis including light inten-

\section{Factors associated with neoatherosclerotic change}

Several factors may be associated with the vessel healing process after implantation of DES. In the previous literatures, DES use as compared to bare metal stent, diabetes, inadequate lipid control, and native atherosclerosis progression were associated with neoatherosclerosis [21-24]. Procedural factors and clinical presentation would also have a significant impact on the neointimal characteristics represented by the light property values $[25,26]$. The effect of BP-DES was assessed with the multivariate linear regression model with an adjustment including following factors: sex, acute coronary syndrome (angina type), hypertension, diabetes mellitus, statin use, age, current smoker, followup duration, and prasugrel use (Table 4). The present study demonstrated that, usage of BP-DES had, at least in the very short-term follow-up, a major impact on light intensity, light attenuation and backscatter, whereas other factors had a limited impact. A prospective and long-term clinical association sity (A), light attenuation (B), and backscatter $(\mathbf{C})$. Neointimal area was separated into two parts: (1) superficial neointima, and (2) deep neointima

of the patients' factors with the neointimal characteristics should be investigated.

\section{Clinical Implication}

The present study demonstrated the comparable coverage percent and neointimal thickness at 3-month follow-up. However, the light property analysis demonstrated that the light characteristics of the neointima following implantation of BP- and DP-DES were significantly different. These results suggested the importance of not only percent coverage but also quality assessment of the neointima when we evaluate the vessel healing on OCT especially at very acute phase.

In our recent clinical practice, duration of DAPT is getting shorter based on the results of short DAPT studies [14, 27]. Imaging assessments particularly by OCT can provide precise insights into the vessel healing and will be helpful to establish a background of ultra-short DAPT strategy. Serial imaging assessment at very early phase (1, 2, 3 months) is 


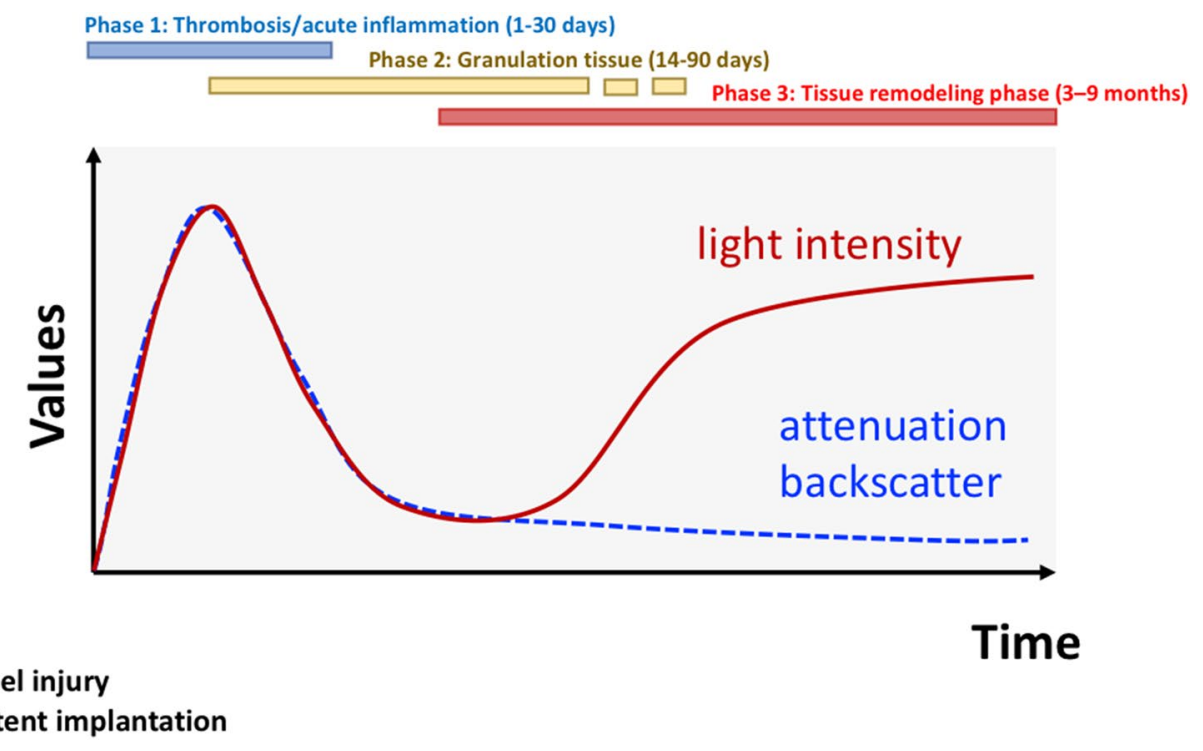

Fig. 5 Theoretical change of the light property values in acute phase. Vascular healing process following vessel injury by metallic stent implantation was previously reported based on the autopsy data $[18,19]$. The vessel healing process can be divided into 3 different phases: (1) thrombosis/acute inflammation, (2) granulation tissue, and (3) tissue remodeling phase. Considering the predominant cellular components in each phase, we can speculate the theoretical changes of the light property values as follows: Phase 1: Thrombosis/acute inflammation (1-30 days) Endothelium injury by stent implantation leads to the response of the activation of platelets and their deposition at the site of the lesion, with recruitment of circulating leucocytes. The platelet/fibrin/erythrocyte deposition occurs in the first 24-48 hours. Acute inflammatory cells can be identified within the platelet/fibrin aggregates around the stent struts. Erythrocyte contains a large amount of lipid in its membrane (40\%) [16]. In this phase, thrombus with erythrocytes and inflammatory cells would indicate high intensity with high attenuation. Phase 2: Granulation tissue (14-90 days) The endothelial cells proliferate and migrate over the injured areas while smooth muscle cells and macrophages replace the fibrin clot with granulation tissue. The newly formed vascularized

required to elucidate the vessel healing process of the contemporary DES. Quantitative light property analysis would be useful and advantageous over visual assessment to evaluate the quality of tissue coverage.

\section{Study strength and limitation}

The methodology we employed in the present analysis was highly objective and reproducible, making the results reproducible and reliable. However, some limitations should to be acknowledged. First, study design was a single center observational study and the sample size was relatively small, albeit the well-balanced patient demographics. Second, only one time point assessment ( 3 months) could not provide indepth insights into the difference in progression of neointimal coverage between BP- and DP-DES. Third, difference amongst the analyzed stents [Synergy ${ }^{\mathrm{TM}}$, Ultimaster ${ }^{\mathrm{TM}}$, tissue includes macrophages which are responsible for phagocytosis of cell debris as well as secretion of growth factors, chemokines and cytokines. Light intensity and attenuation/backscatter would theoretically decrease in this phase. Phase 3: Tissue remodeling phase (3-9 months) The hallmark of this phase is the modification of smooth muscle cells activated by growth factors/cytokines produced by the injured endothelium and media, platelets, and infiltrated inflammatory cells as well as by the compressive forces generated in the vessel wall by the stent placement along with low shear stress induced by stent struts. Neointimal smooth muscle cells proliferate during 3-9 months with production of varying amount of extracellular matrix. The first phase of matrix formation is the formation of provisional matrix which is formed by the plasma proteins such as fibrin, fibrinogen, and fibronectin. In early phase, fiber rich extracellular matrix, infrequent smooth muscle cells, and interspersed inflammatory cells would show lower signal intensity values and lower attenuation/backscatter. In late phase, mature neointimal tissue with a predominance of smooth muscle cells would show higher greyscale signal intensity values and lower attenuation/backscatter values

Xience $^{\mathrm{TM}}$, Resolute Integrity ${ }^{\mathrm{TM}}$, and Resolute Onyx ${ }^{\mathrm{TM}}$ ] is not only the polymer degradation type but also strut design, strut shape, strut material, strut thickness, polymer coating type (abluminal coating, circumferential coating), polymer degradation speed, drug type, drug releasing speed, drug concentration, etc. These confounders were not fully adjusted in the present analysis. Along the same lines, both BP-DES and DP-DES still keep polymer at 3 months followup, although the bioresorption process presumably influence on the neointimal characteristics. Lastly, the direct impact of these findings on clinical outcome remains to be elucidated. We plan to assess the light property of the neointima again at the chronic phase (2 years) in the RESTORE registry and evaluate clinical impacts of this imaging surrogates on 2-year outcomes. Due to the inherent limitations of the current study design, the results would be hypothesis-generating and should be interpreted with caution. Further prospective 
randomized trials would be warranted to obtain a robust conclusion.

\section{Conclusion}

Almost complete coverage at 3 months in both contemporary BP- and DP-DES would support the ultra-short DAPT strategy in the upcoming decade. Nevertheless, there was a significant difference in the neointimal characteristics on OCT light property 3 months after BP- vs. DP-DES implantation. Further prospective randomized trials should be conducted to re-evaluate the current hypothesis-generating results and to investigate the clinical significance of the present imaging results.

\section{Compliance with ethical standards}

Conflict of interest Y. Sotomi, S. Nakatani, and Y. Higuchi received speaker honoraria from Abbott Vascular Japan, Boston Scientific Japan, TERUMO, Cardinal Health, and Medtronic. Y. Onuma and P. Serruys are members of the Advisory Board for Abbott Vascular.A. Hirayama reports grants and personal fees from Boston Scientific Japan, Abbott Vascular Japan, Japan Lifeline, and Medtronic. Y. Sakata reports grants and personal fees from Daiichi-Sankyo, Bayer, Boehringer Ingelheim, and Bristol-Myers Squibb. The authors have no other relevant affiliations or financial involvement with any organization or entity with a financial interest in or financial conflict with the subject matter or materials discussed in the manuscript apart from those disclosed.

\section{References}

1. Tellez A, Seifert PS, Donskoy E, Sushkova N, Pennington DE, Milewski K, Krueger CG, Kaluza GL, Eppihimer MJ, Huibregtse BA, Dawkins KD, Granada JF (2014) Experimental evaluation of efficacy and healing response of everolimus-eluting stents in the familial hypercholesterolemic swine model: a comparative study of bioabsorbable versus durable polymer stent platforms. Coron Artery Dis 25(3):198-207. https://doi.org/10.1097/mca.00000 00000000099

2. Chevalier B, Smits PC, Carrie D, Mehilli J, Van Boven AJ, Regar E, Sawaya FJ, Chamie D, Kraaijeveld AO, Hovasse T, Vlachojannis GJ (2017) Serial assessment of strut coverage of biodegradable polymer drug-eluting stent at 1,2 , and 3 months after stent implantation by optical frequency domain imaging: the DISCOVERY 1TO3 study (evaluation with ofdi of strut coverage of terumo new drug eluting stent with biodegradable polymer at 1,2 , and 3 months). Circ Cardiovasc Interv. https://doi.org/10.1161/circinterv entions.116.004801

3. El-Hayek G, Bangalore S, Casso Dominguez A, Devireddy C, Jaber W, Kumar G, Mavromatis K, Tamis-Holland J, Samady H (2017) Meta-analysis of randomized clinical trials comparing biodegradable polymer drug-eluting stent to second-generation durable polymer drug-eluting stents. JACC Cardiovasc Interv 10(5):462-473. https://doi.org/10.1016/j. jcin.2016.12.002
4. Sotomi Y, Onuma Y, Liu S, Asano T, Eggermont J, Katagiri Y, Cavalcante R, de Winter RJ, Wykrzykowska JJ, Brugaletta S, Raber L, Sabate M, Windecker S, Dijkstra J, Serruys PW (2018) Quality difference of neointima following the implantation of everolimus-eluting bioresorbable scaffolds and metallic stents in patients with ST-elevation myocardial infarction: quantitative assessments by light intensity, light attenuation, and backscatter on optical coherence tomography in the TROFI II trial. EuroIntervention 14 (6):678-685. https://doi.org/10.4244/eij-d-17-00884

5. Imanaka T, Fujii K, Hao H, Shibuya M, Saita T, Kawakami R, Fukunaga M, Kawai K, Tamaru H, Miki K, Horimatsu T, Sumiyoshi A, Nishimura M, Hirota S, Masuyama T, Ishihara M (2016) Ex vivo assessment of neointimal characteristics after drug-eluting stent implantation: Optical coherence tomography and histopathology validation study. Int J Cardiol 221:1043-1047. https:// doi.org/10.1016/j.ijcard.2016.07.110

6. Xu C, Schmitt JM, Carlier SG, Virmani R (2008) Characterization of atherosclerosis plaques by measuring both backscattering and attenuation coefficients in optical coherence tomography. J Biomed Optics 13(3):034003. https://doi.org/10.1117/1.2927464

7. Suzuki S, Sotomi Y, Kobayashi T, Hamanaka Y, Nakatani S, Shiojima I, Sakata Y, Hirayama A, Higuchi Y (2019) Early vessel healing after implantation of biodegradable-polymer and durablepolymer drug-eluting stent: 3-month angioscopic evaluation of the RESTORE registry. Int J Cardiovasc Imaging. doi:https://doi. org/10.1007/s10554-019-01580-2

8. Liu S, Sotomi Y, Eggermont J, Nakazawa G, Torii S, Ijichi T, Onuma Y, Serruys PW, Lelieveldt BPF, Dijkstra J (2017) Tissue characterization with depth-resolved attenuation coefficient and backscatter term in intravascular optical coherence tomography images. J Biomed Optics 22(9):1-16. https://doi.org/10.1117/1. Jbo.22.9.096004

9. Nakatani S, Sotomi Y, Ishibashi Y, Grundeken MJ, Tateishi H, Tenekecioglu E, Zeng Y, Suwannasom P, Regar E, Radu MD, Raber L, Bezerra H, Costa MA, Fitzgerald P, Prati F, Costa RA, Dijkstra J, Kimura T, Kozuma K, Tanabe K, Akasaka T, Di Mario C, Serruys PW, Onuma Y (2016) Comparative analysis method of permanent metallic stents (XIENCE) and bioresorbable polyL-lactic (PLLA) scaffolds (Absorb) on optical coherence tomography at baseline and follow-up. EuroIntervention 12 (12):14981509. https://doi.org/10.4244/eijy15m10_03

10. Barbato E, Salinger-Martinovic S, Sagic D, Beleslin B, Vrolix M, Neskovic AN, Jagic N, Verheye S, Mehmedbegovic Z, Wijns W (2015) A first-in-man clinical evaluation of Ultimaster, a new drug-eluting coronary stent system: CENTURY study. EuroIntervention 11 (5):541-548. https://doi.org/10.4244/eijy14m08_06

11. de la Torre Hernandez JM, Tejedor P, Camarero TG, Duran JM, Lee DH, Monedero J, Laso FS, Calderon MA, Veiga G, Zueco J (2016) Early healing assessment with optical coherence tomography of everolimus-eluting stents with bioabsorbable polymer (synergy) at 3 and 6 months after implantation. Catheter Cardiovasc Interv 88(3):E67-E73. https://doi.org/10.1002/ccd.26299

12. Kim S, Kim JS, Shin DH, Kim BK, Ko YG, Choi D, Cho YK, Nam CW, Hur SH, Jang Y, Hong MK (2013) Comparison of early strut coverage between zotarolimus- and everolimus-eluting stents using optical coherence tomography. Am J Cardiol 111(1):1-5. https://doi.org/10.1016/j.amjcard.2012.08.037

13. Konishi A, Iwasaki M, Shinke T, Otake H, Takaya T, Osue T, Nishio R, Kinutani H, Kuroda M, Takahashi H, Terashita D, Shite J, Hirata KI (2018) Favorable early vessel healing after everolimus-eluting stent implantation: 3-, 6-, and 12-month follow-up of optical coherence tomography. J Cardiol 72(3):193-199. https:// doi.org/10.1016/j.jjcc.2018.04.005

14. Varenne O, Cook S, Sideris G, Kedev S, Cuisset T, Carrie D, Hovasse T, Garot P, El Mahmoud R, Spaulding C, Helft G, Diaz Fernandez JF, Brugaletta S, Pinar-Bermudez E, Mauri Ferre 
J, Commeau P, Teiger E, Bogaerts K, Sabate M, Morice MC, Sinnaeve PR (2018) Drug-eluting stents in elderly patients with coronary artery disease (SENIOR): a randomised single-blind trial. Lancet 391(10115):41-50. https://doi.org/10.1016/s0140 $-6736(17) 32713-7$

15. Malle C, Tada T, Steigerwald K, Ughi GJ, Schuster T, Nakano M, Massberg S, Jehle J, Guagliumi G, Kastrati A, Virmani R, Byrne RA, Joner M (2013) Tissue characterization after drug-eluting stent implantation using optical coherence tomography. Arteriosclerosis, thrombosis, and vascular biology 33 (6):1376-1383. doi:https://doi.org/10.1161/atvbaha.113.301227

16. Nayak BS, Beharry VY, Armoogam S, Nancoo M, Ramadhin K, Ramesar K, Ramnarine C, Singh A, Singh A, Nwachi KU, Teelucksing S, Mathura R, Roberts L (2008) Determination of RBC membrane and serum lipid composition in Trinidadian type II diabetics with and without nephropathy. Vasc Health Risk Manag 4(4):893-899

17. Kolodgie FD, Gold HK, Burke AP, Fowler DR, Kruth HS, Weber DK, Farb A, Guerrero LJ, Hayase M, Kutys R, Narula J, Finn AV, Virmani R (2003) Intraplaque hemorrhage and progression of coronary atheroma. N Engl J Med 349(24):2316-2325. https ://doi.org/10.1056/NEJMoa035655

18. Chaabane C, Otsuka F, Virmani R, Bochaton-Piallat ML (2013) Biological responses in stented arteries. Cardiovasc Res 99(2):353-363. https://doi.org/10.1093/cvr/cvt115

19. Nakano M, Virmani R (2015) Histopathology of vascular response to drug-eluting stents: an insight from human autopsy into daily practice. Cardiovasc Interv Ther 30(1):1-11. https://doi. org/10.1007/s12928-014-0281-5

20. Kobayashi T, Sotomi Y, Suzuki S, Suwannasom P, Nakatani S, Morino Y, Ako J, Kozuma K, Hirayama A, Sakata Y, Higuchi Y (2019) Five-year clinical efficacy and safety of contemporary thin-strut biodegradable polymer versus durable polymer drugeluting stents: a systematic review and meta-analysis of 9 randomized controlled trials. Cardiovasc Interv Therap. https://doi. org/10.1007/s12928-019-00613-w

21. Jang JY, Kim JS, Shin DH, Kim BK, Ko YG, Choi D, Jang Y, Hong MK (2015) Favorable effect of optimal lipid-lowering therapy on neointimal tissue characteristics after drug-eluting stent implantation: qualitative optical coherence tomographic analysis. Atherosclerosis 242(2):553-559. https://doi.org/10.1016/j.ather osclerosis.2015.08.014

22. Hong YJ, Jeong MH, Choi YH, Park SY, Rhew SH, Kim SS, Jeong YW, Jeong HC, Cho JY, Jang SY, Lee KH, Park KH, Sim
DS, Yoon NS, Yoon HJ, Kim KH, Park HW, Kim JH, Ahn Y, Cho JG, Park JC (2014) Relation between renal function and neointimal tissue characteristics after drug-eluting stent implantation: virtual histology-intravascular ultrasound analysis. J Cardiol 64(2):98-104. https://doi.org/10.1016/j.jjcc.2013.11.019

23. Taniwaki M, Windecker S, Zaugg S, Stefanini GG, Baumgartner S, Zanchin T, Wenaweser P, Meier B, Juni P, Raber L (2015) The association between in-stent neoatherosclerosis and native coronary artery disease progression: a long-term angiographic and optical coherence tomography cohort study. Eur Heart J 36(32):2167-2176. https://doi.org/10.1093/eurheartj/ehv227

24. Vergallo R, Yonetsu T, Uemura S, Park SJ, Lee S, Kato K, Jia H, Abtahian F, Tian J, Hu S, Lee H, McNulty I, Prasad A, Yu B, Zhang S, Porto I, Biasucci LM, Crea F, Jang IK (2013) Correlation between degree of neointimal hyperplasia and incidence and characteristics of neoatherosclerosis as assessed by optical coherence tomography. Am J Cardiol 112(9):1315-1321. https:// doi.org/10.1016/j.amjcard.2013.05.076

25. Sotomi Y, Onuma Y, Dijkstra J, Eggermont J, Liu S, Tenekecioglu E, Zeng Y, Asano T, de Winter RJ, Popma JJ, Kozuma K, Tanabe K, Serruys PW, Kimura T (2016) Impact of implantation technique and plaque morphology on strut embedment and scaffold expansion of polylactide bioresorbable scaffold- insights from ABSORB Japan Trial. Circ J 80(11):2317-2326. https://doi. org/10.1253/circj.CJ-16-0818

26. Sotomi Y, Tateishi H, Suwannasom P, Dijkstra J, Eggermont J, Liu S, Tenekecioglu E, Zheng Y, Abdelghani M, Cavalcante R, de Winter RJ, Wykrzykowska JJ, Onuma Y, Serruys PW, Kimura T (2016) Quantitative assessment of the stent/scaffold strut embedment analysis by optical coherence tomography. Int J Cardiovasc Imaging 32(6):871-883. https://doi.org/10.1007/s1055 4-016-0856-6

27. Naidu SS, Krucoff MW, Rutledge DR, Mao VW, Zhao W, Zheng Q, Wilburn O, Sudhir K, Simonton C, Hermiller JB (2012) Contemporary incidence and predictors of stent thrombosis and other major adverse cardiac events in the year after XIENCE V implantation: results from the 8,061-patient XIENCE V United States study. JACC Cardiovasc Interv 5(6):626-635. https://doi. org/10.1016/j.jcin.2012.02.014

Publisher's Note Springer Nature remains neutral with regard to jurisdictional claims in published maps and institutional affiliations. 